\title{
Influence of Iwans on the Thermal Comfort of Talar Rooms in the Traditional Houses: A Study in Shiraz, Iran
}

\author{
Jalil Shaeri $^{1, *}$, Mahmood Yaghoubi ${ }^{2}$ (D) and Amin Habibi ${ }^{1}$ \\ 1 Faculty of Arts and Architecture, Shiraz University, Shiraz 7188637911, Iran; a_habibi@shirazu.ac.ir \\ 2 School of Mechanical Engineering, Shiraz University, Shiraz 7193616548, Iran; yaghoubi@shirazu.ac.ir \\ * Correspondence: shaer.jalil@gmail.com or jalil.shaeri@shirazu.ac.ir; Tel.: +98-937-305-6253
}

Received: 11 May 2018; Accepted: 12 June 2018; Published: 13 June 2018

\begin{abstract}
In traditional buildings many climatic strategies have been used to provide indoor thermal comfort in south and central parts of Iran. A common element is called an iwan. This study investigates the indoor thermal comfort of a room adjoined to a talar in a traditional house which has an iwan, in Shiraz, Iran. The data related to the temperature and relative humidity of the room are used to calculate the thermal comfort index of PMV (Predicted Mean Vote) and PPD (Predicted Percentage of Dissatisfied) by considering the following two cases: a talar room with an iwan and one without an iwan, by means of DesignBuilder software. For the purpose of validation, the air temperature and relative humidity of the talar room with an iwan were measured over 10 days and compared to the results of the simulation. Having a valid simulation, computation was conducted for the selected house in various cases for an annual passive operation of calculating PMV and PPD. The numerical results revealed that the talar room adjoined to an iwan located in the south front of the courtyard had relatively good conditions during the hot months, including June and July. In addition, it could provide fully satisfactory comfort conditions during August and September. According to the results, it is found that the iwan makes a talar room $62 \%$ more desirable for the hot months in comparison with a talar room without an iwan.
\end{abstract}

Keywords: iwan; thermal comfort; talar; traditional houses; PMV; PPD; indoor quality environment (IQE)

\section{Introduction}

Today, a considerable amount of energy is spent on heating and cooling indoor environments to provide thermal comfort for the building's residents. The availability of modern heating and cooling systems has led to little attention being paid to passive systems in modern architecture [1,2]. Greenhouse gas emissions and global warming in recent years, in addition to high energy consumption in residential sectors, have caused the emergence of a greater interest in climatic strategies. Meanwhile, more effort is devoted to using such strategies in local and traditional architecture in modern buildings [3-5]. For a long period of time, buildings and climatic strategies have been constructed based on trial and error for local and traditional buildings; however, these experiences are going to be forgotten [6,7].

Most traditional buildings in hot and dry climates have been comfortable for residences thanks to their passive temperature control systems. Also, in comparison to modern buildings, they consume less energy for air conditioning [8]. Comparisons between traditional and contemporary houses have indicated that traditional houses, which employ building design strategies, are more compatible with the environment, resulting in better thermal comfort in indoor spaces. Although in contemporary houses many technologies are used to achieve indoor thermal comfort [9-11], several studies have 
indicated that passive and climatic strategies used in traditional buildings can be implemented in modern buildings [12].

Regarding traditional materials, the study of Ashrae revealed that using brick and rubble and muddy blocks in traditional houses, in comparison to the stones used in these houses, influences energy consumption in a way that leads to lower energy consumption in indoor spaces [13].

In addition, in some traditional buildings, underground space was used to take advantage of the cooling capacity of the soil, in order to cool the space and ground floor [14]. Meanwhile, materials with high thermal capacity were used to control the temperature fluctuations; interior and exterior walls were very thick and ceilings were insulated [15].

Other climatic strategies to cool indoor spaces in traditional buildings included using the forms of central courtyards, creating a semi-open spaces, and employing porches and balconies $[16,17]$. Bright colors are used in these buildings, as well as double and several skin ceilings and domes [18,19]. Entrance filters and intermediate spaces are applied to preserve the heat or coolness of the indoor space [20]. In order to increase humidity, ponds and trees were used in hot and dry climate, and wind catchers in several forms were applied to take advantage of wind flow. Also, windows were considered to direct the air from the central courtyard to the upper rooms $[9,15,21]$. In some buildings, houses have two parts, one for summer settlement and another for winter occupation [22], and for each side of the house the central courtyard is devoted to one season [7]. Orientations of these buildings were usually toward the southeast and a dense pattern of urbanization was commonly used in organizing such buildings [9].

The most important climatic characteristic in most traditional houses of Iran in the warm and dry climate is the iwan with a high vault, which is considered useful for all activities of life. One of its sides is open, overlooking the yard, and the other two sides are half closed. The fourth side is closed, which may take one of several forms and has been made with various materials and sizes in different areas and cities, as shown in Figure 1. The closet space is called the talar. The talar room often has a sash and grille made of wood and glass. Foruzanmehr [21] studied iwans and talars of traditional houses in Yazd, Iran, in a qualitative way and indicated that residents were satisfied with the space of the iwan and talar as it enabled communication with outdoor space in addition to providing privacy and thermal comfort. Atrvash and Fayaz [23] studied the effect of sash windows in three positions of open, semi-closed, and closed on the flow indoor, which were simulated by COMSOL software (version 3.3a, Comsol Multiphysics, Stockholm, Sweden). Their studies showed that sashes in the open position conducted flow directly from the courtyard toward the top of the room, which resulted in the movement and rotation of air in a considerable volume of the room. For semi-closed sashes, limited flow in the bottom of the room with a lower volume of movement took place.

As an effective strategy, courtyards were also used in the vernacular architecture to bring suitable thermal conditions to the residential buildings. A study by Ryu et al. [24] indicated that due to cold weather between the yard and the backyard of traditional houses, the temperature difference could provide a comfortable situation for the indoor environment. The differences between the temperatures in the designed courtyards created mild air velocity in the adjacent rooms. In a study of a vernacular house in Oman, the sea breeze was used to moderate the high relative humidity inside the house by means of natural ventilation [25]. In general, vernacular houses near coastal areas have been designed sophisticatedly to lead wind directly and indirectly to buildings [26]. In order to apply wind sufficiently in these buildings and use maximum sunlight in the cold seasons, buildings have been orientated in the east-west direction [4].

Shading devices have been installed horizontally and vertically on top of windows and apertures have been employed, especially in the south direction, to sufficiently fulfill heat avoidance techniques. By controlling intensive solar radiation through the application of shadings in balconies as well as the increase of cross-ventilation through the shaded windows, acceptable indoor thermal conditions have been supplied in vernacular houses $[4,5,27]$. 
Lighter colors on the outer surfaces and local materials with low thermal conductivity such as wood, bamboo or palm tree trunks, stone, mud, and lime are used in buildings to reduce the transformation of heat from outside to the inside [28]. The central courtyard in this region is small so as to receive less sunlight during the day. The heat is easily transferred to the surrounded environment during the nighttime through the external surfaces of the courtyard and roof. This in turn helps the building to act as a heat sink and remove the heat quickly [27].

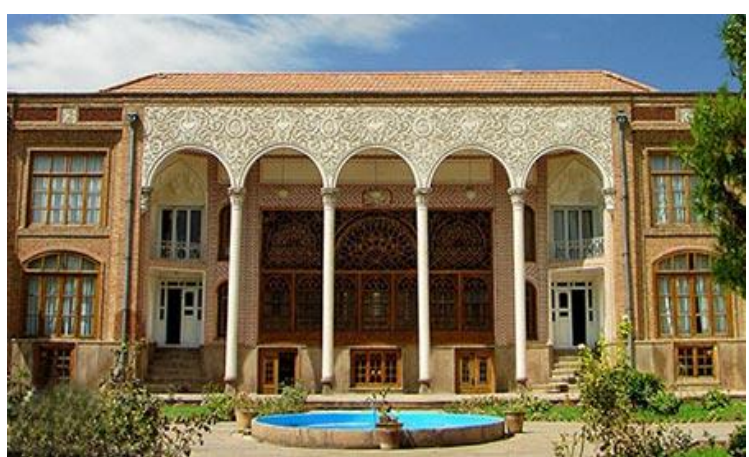

(a)

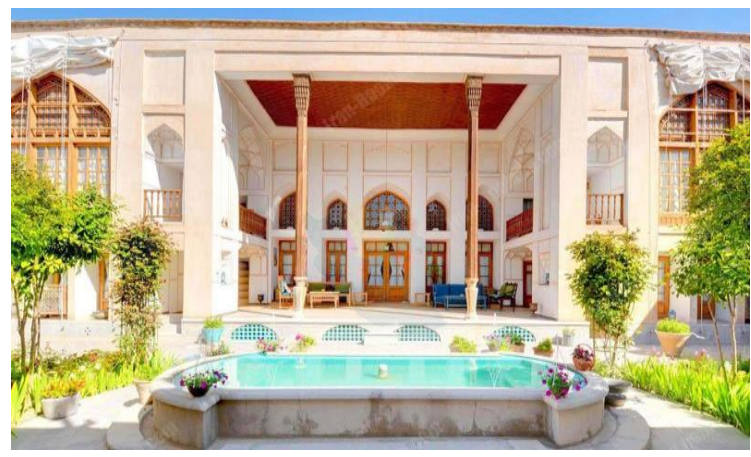

(c)

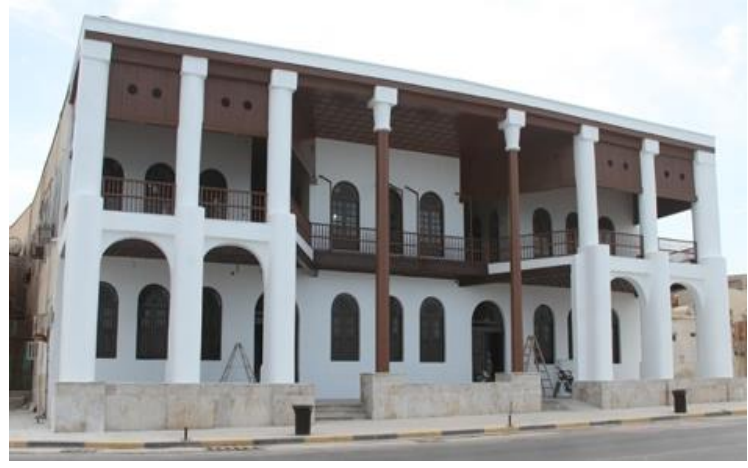

(e)

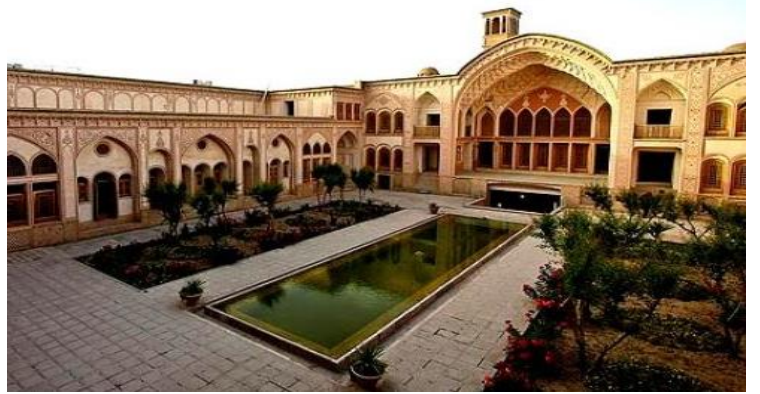

(b)

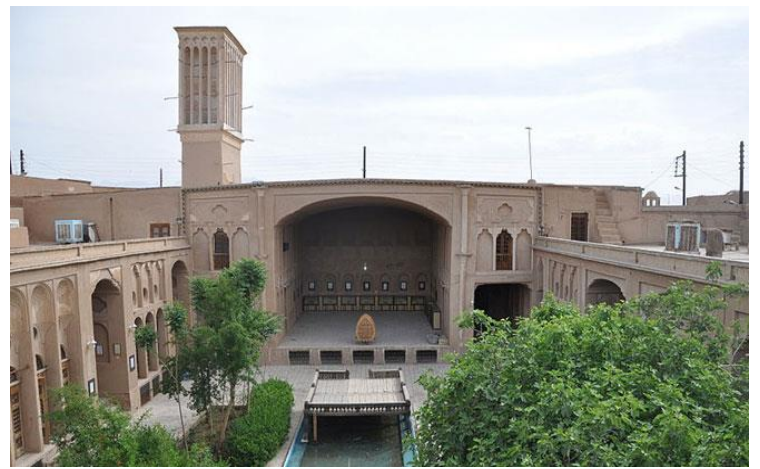

(d)

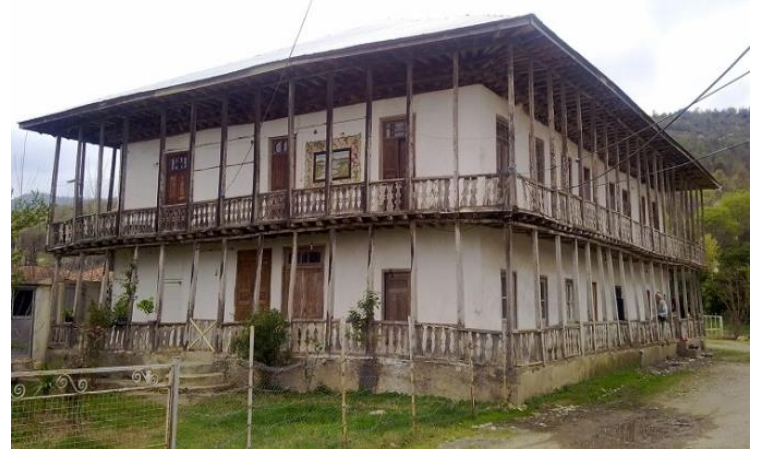

(f)

Figure 1. Iwans of Iran's traditional buildings in different climates: (a) iwan of Behnam house in Tabriz (cold climate); (b) iwan of Boroujerdi house in Kashan (hot and dry climate); (c) iwan of Bekhradi house in Esfehan (hot and dry climate); (d) iwan of Lariha house in Yazd (hot and dry climate); (e) iwan of Amirieh house in Bushehr (hot and humid climate); (f) iwan of Rahimi house in Bitam village, Anzali (mild and humid climate). 
Fernandes et al. [29] studied the climate strategies in vernacular architecture from the northern and southern parts of Portugal, specifically in the Beira Alta and Alentejo areas, respectively. They selected a case study and used experimental tests to obtain measurements of hygrothermal and surveyed thermal sensations on occupants. Their results indicated that the vernacular houses showed good thermal performance by passive strategies and the occupants felt thermal comfort. However, the occupants needed to use simple heating systems during the winter. Glazed balconies which were used in Beira Alta played a good strategy role receiving solar gains; in Alentejo, the focus was on passive cooling strategies and courtyards represented a good strategy for shading to reduce temperature. Another study investigated the thermal conditions of a vernacular building in Evora, Portugal. The results revealed that the passive cooling techniques used in vernacular buildings can improve indoor thermal comfort during the summer season. The difference between the indoor temperature and the maximum outdoor temperature in the courtyard and in the city center was respectively $7{ }^{\circ} \mathrm{C}$ and $16{ }^{\circ} \mathrm{C}$. Several passive strategies used in vernacular houses can be mentioned as follows: small exterior doors and windows, high thermal inertia walls, white washed walls, courtyards, and patios. These vernacular strategies have great potential for decreasing energy consumption in modern buildings [30]. In addition, Fernandes et al. [31] investigated the thermal performance and comfort of vernacular buildings in Egypt and Portugal. The results showed the correlation between the thermal performance of vernacular buildings and human comfort perception in two different case studies located in the Mediterranean climate. It was revealed that the common passive techniques in both cases were different, based on the site selection. However, overall, vernacular passive strategies can be used to achieve indoor thermal comfort and reduce loads of mechanical systems.

Kubota and Toe [32] investigated how passive cooling strategies in vernacular houses were used in modern houses to reduce energy consumption in Malaysia. They used experimental measurements in two traditional timber Malay houses and two traditional masonry Chinese shop houses, then they investigated indoor thermal environments and passive cooling techniques in the case studies. The results revealed that the indoor air temperature of rooms adjacent to courtyards was lower than the outdoor temperature by up to $5-6{ }^{\circ} \mathrm{C}$ during the day. In addition, the indoor air temperature of rooms was similar to the outdoor temperature at night. They determined an adaptive thermal comfort equation for hot-humid climates. The indoor operative temperature reached more than $80 \%$ comfort in the Malay houses and Chinese shop houses. Passive strategies in vernacular houses included night ventilation, roof and ceiling insulation, window and wall shading, and courtyards.

Alrashed et al. [33] investigated the roles of Mashrabiyah, courtyards, and adobe construction for Dhahran, Guriat, Riyadh, Jeddah, and Khamis Mushait in Saudi Arabia. They designed a base and then calculated the electricity value of the houses adjusted with these passive strategies and materials. Their results revealed that in terms of energy saving, courtyards are not useful. Using Mashrabiyah can reduce energy consumption by $4 \%$ and $3 \%$, and adobe can reduce energy consumption by $6 \%$ and $19 \%$. Also in Chinese houses in a hot and humid climate, courtyard, patio, and semi-open spaces are used to create indoor thermal comfort [34]. Different types of courtyards of Chinese vernacular houses in a hot and humid climate perform different functions in improving indoor thermal comfort [35]. Another study indicated that using Shavadan spaces in traditional houses in a hot and humid climate can create thermal comfort and help to reduce cooling and heating loads [36]. Studies of passive strategies in vernacular houses in India revealed the relation of vernacular architectural features to thermal comfort conditions [13,37]. In addition, replacing rubble stone masonry with burnt clay brick masonry and stabilized soil block masonry was found to increase the embodied energy of the dwelling by 9.7 times $(870 \%)$ and 2.8 times (182\%), respectively [13]. Applying traditional materials, such as adobe, could be the best option in hot and humid climates [38].

Different parameters influence the thermal comfort of the individuals in closed environments. For instance, the value of insufficiency of clothing influences the thermal transaction between the human body and environment. In addition, the speed of the flaw (the appropriate amount of which is 
variable) and the amount of individual labor (which specifies the rhythm of metabolism) should be determined [39].

Mean radiant temperature was calculated in assessment of thermal comfort, which is the relationship between the radiant and room surfaces (floor, ceiling and walls) [39]. The two factors of relative humidity and air temperature have a great effect on an individual's thermal comfort. A relative humidity less than $30 \%$ may result in dry skin, eye irritation, and breathing problems, while a relative humidity (RH) higher than $60 \%$ may result in an environment suitable for mold growth and allergic problems [40].

According to ISO 7730 [41], to assess thermal comfort the two indicators of PMV (Predicted Mean Vote) and PPD (Predicted Percentage of Dissatisfied) were determined and the dissatisfaction rate was expressed by percentage. PMV has different borders and each has a different meaning, as listed in Table 1.

Table 1. The thermal comfort index PMV (Predicted Mean Vote) and its relationship to thermal sensitivity [41].

\begin{tabular}{cc}
\hline PMV & Thermal Sensitivity \\
\hline+3 & Hot \\
+2 & Warm \\
+1 & Slightly warm \\
0 & Neutral \\
-1 & Slightly cool \\
-2 & Cool \\
-3 & Cold \\
\hline
\end{tabular}

In this index, the thermal sensitivity of the environment is divided across the range from hot to cold. The PMV value is determined using Equation (1).

$$
\begin{aligned}
\text { PMV }= & \left(0.303 \mathrm{e}^{-0.036 \mathrm{M}}+0.028\right) \cdot\left\{(\mathrm{M}-\mathrm{W})-3.05 \times 10^{-3}\left[5733-6.99(\mathrm{M}-\mathrm{W})-\mathrm{P}_{\mathrm{W}}\right.\right. \\
- & 0.42[(\mathrm{M}-\mathrm{W})-5815]-1.7 \times 10^{-5}\left(5867-\mathrm{P}_{\mathrm{a}}\right)-0.0014 \mathrm{M}\left(34-\mathrm{T}_{\mathrm{a}}\right) \\
& \left.-3.96 \times 10^{-8} \cdot \mathrm{f}_{\mathrm{cl}}\left[\left(\mathrm{T}_{\mathrm{cl}}+273\right)^{4}-\left(\mathrm{T}_{\mathrm{r}}+273\right)^{4}\right]-\mathrm{f}_{\mathrm{cl}} \mathrm{h}_{\mathrm{c}}\left(\mathrm{T}_{\mathrm{cl}}-\mathrm{T}_{\mathrm{a}}\right)\right\}
\end{aligned}
$$

In which $\mathrm{M}=$ metabolic free energy production $\left(\mathrm{w} / \mathrm{m}^{2}\right), \mathrm{w}=$ external work $\left(\mathrm{w} / \mathrm{m}^{2}\right)$, $\mathrm{Pw}=$ the partial pressure of water, $\mathrm{f}_{\mathrm{cl}}=$ the ratio of clothed $/$ nude surface area, $\mathrm{T}_{\mathrm{cl}}=$ clothing surface temperature $\left({ }^{\circ} \mathrm{C}\right), \mathrm{h}_{\mathrm{cl}}=$ convective transfer coefficient $\left(\mathrm{w} / \mathrm{m}^{2} \mathrm{~K}\right)$, and $\mathrm{T}_{\mathrm{r}}=$ mean radiant temperature $\left({ }^{\circ} \mathrm{C}\right)$. Meanwhile, the PPD value is calculated according to the PMV, which is specified in Equation (2) [41]. PPD is predicted percentage dissatisfied. PPD indicated percentage of dissatisfy people of thermal comfort in indoor room.

$$
P P D=100-95 e^{-\left(0.03353 P M V^{4}+0.2179 P M V^{4}\right)}
$$

Reviewing previous studies revealed that vernacular houses in hot and dry climates have used several strategies in order to create indoor thermal comfort. The performance of vernacular houses is better than that of modern houses. In vernacular houses materials with high thermal capacity, light colors, domed roofs, and wind catchers were used. Underground spaces and semi-open spaces are also used in vernacular houses in hot and dry climates. Courtyards create microclimates in vernacular houses and are very effective in creating indoor thermal comfort. Also, vegetation and water are used for increasing relative humidity. The iwan is a very important element in vernacular houses for the hot and dry climate in Iran. Previous studies have supported this idea and emphasized the effect of iwans on the indoor thermal comfort. However, previous studies on iwans with the approach of considering climate are either qualitative or descriptive. 
Their effect has not yet been studied quantitatively by numerical simulation or the implementation of fieldwork. The purpose of this study is to investigate the role of the iwan on the thermal comfort of a talar room of a traditional house in Shiraz, Iran. The effect of an attached iwan on the thermal condition of the selected room is determined by field measurement and numerical simulation. The full-scale experiment is carried out using various sensors for the evaluation of the current condition of the building as well as the validation of the numerical simulation. Finally, the significant effect of the iwan on the summer passive condition of the adjacent talar is determined and presented for different periods of a year.

\section{Case Study}

Iwans, as shown in Figure 1, are widely used in Iran's traditional buildings for various climate conditions including hot and dry, cold, hot and humid, and mild and humid. Amongst all of the iwans constructed for traditional houses in Iran, iwans belonging to traditional houses in Shiraz were selected as the iwan is considered as an architectural element evident in traditional houses of this city. To make the function of the iwan in traditional buildings obvious, Figure 2 represents how the iwan schematically alleviates the thermal conditions in a traditional house in Shiraz.

Among the traditional houses in Shiraz, the Manteghi-Nezhad house was selected. The iwan of this house represents the most common type of iwan amongst all traditional houses of the city. The Manteghi-Nezhad house was a residential house built in Qajar era (1870-1890). The building includes a ground floor and an underground floor. The house has a flat-roof iwan with two pillars and it opens on a central courtyard, as shown Figure 3.

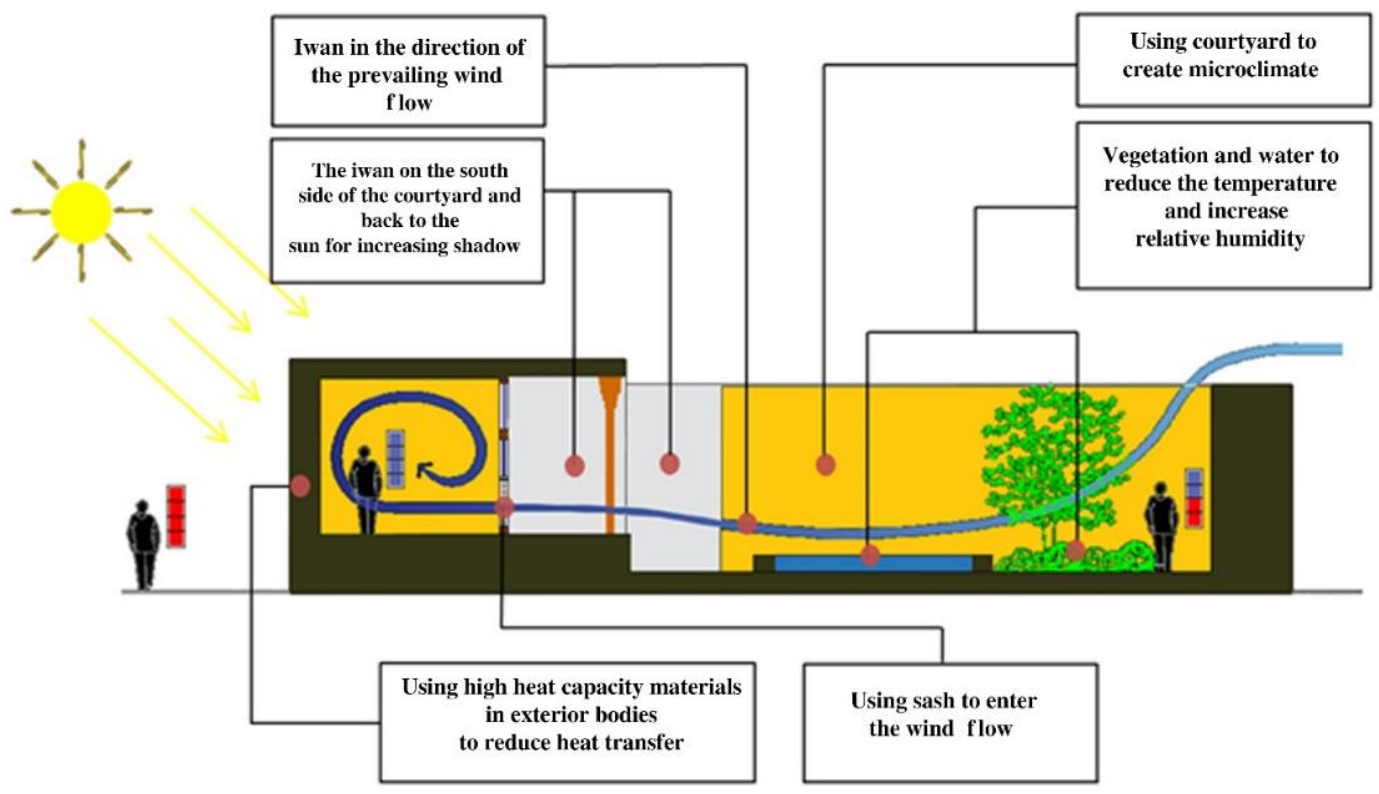

Figure 2. Strategies for creating thermal comfort in traditional houses in Shiraz, Iran. 

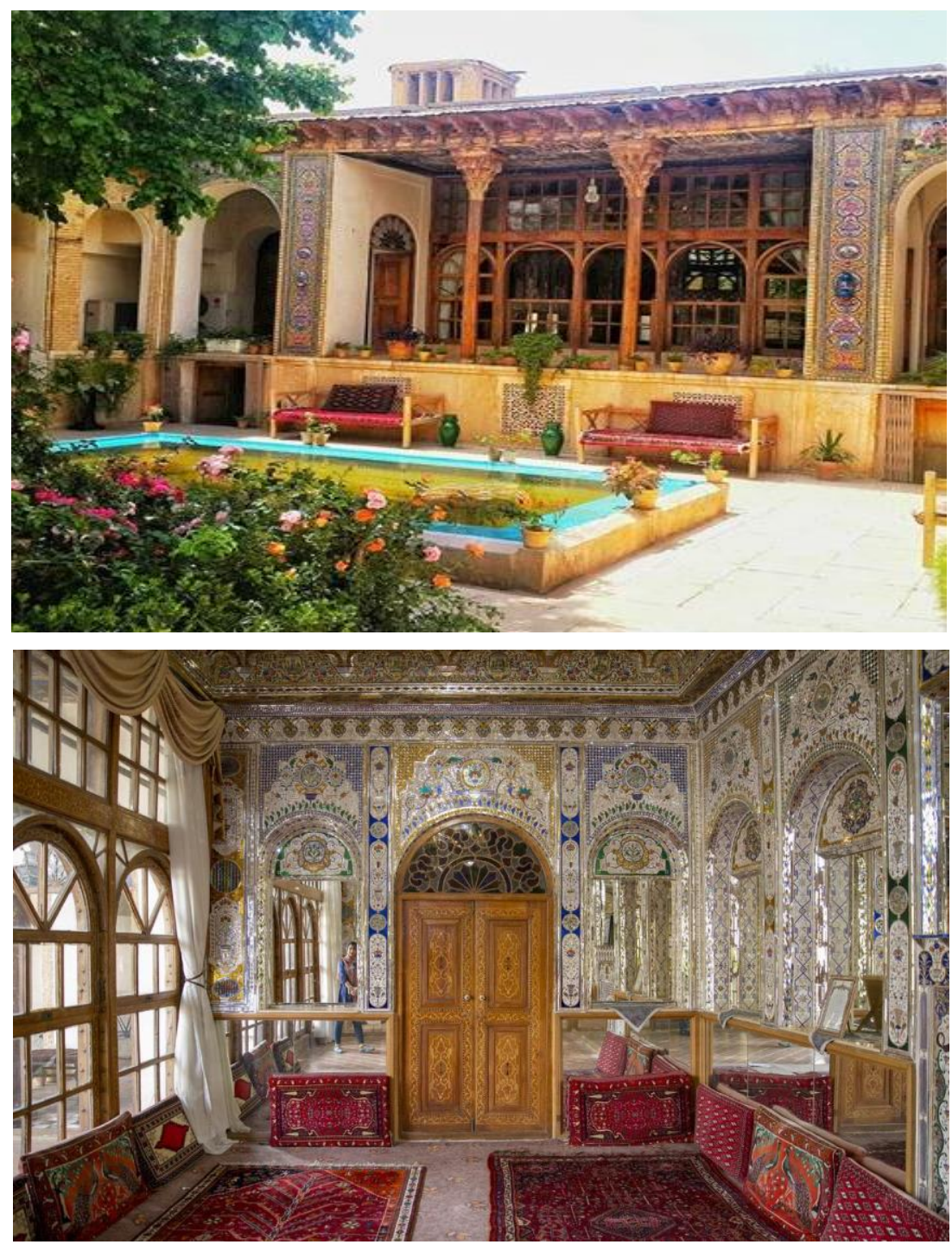

Figure 3. Iwan and talar of the Manteghi-Nezhad house, Shiraz.

Table 2 shows typical traditional houses in Shiraz, which were selected randomly and the pattern of spaces and their interconnections are represented. 
Table 2. Typical traditional houses in Shiraz, which were selected randomly. The pattern of spaces and their interconnections are represented.

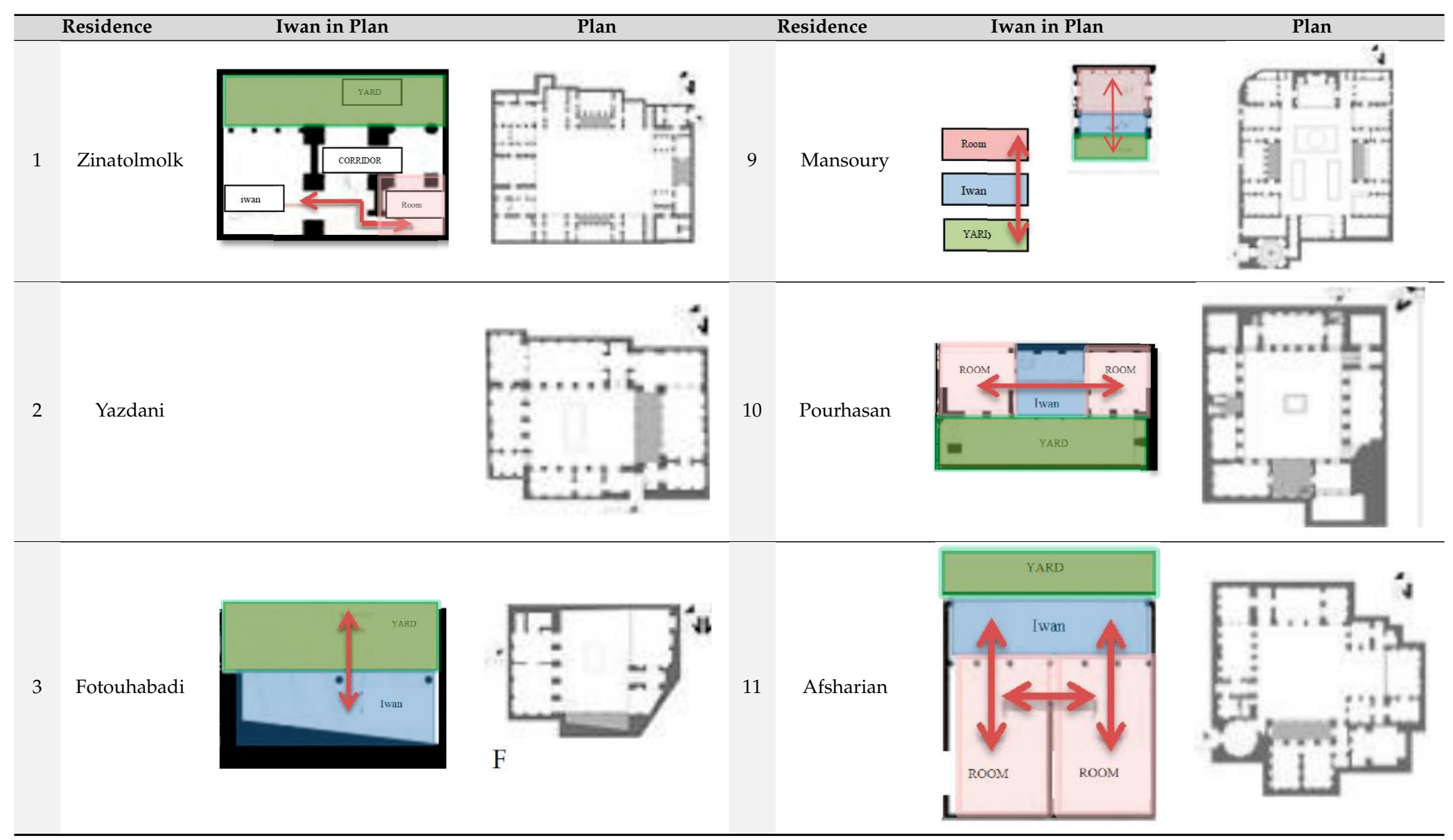


Table 2. Cont.

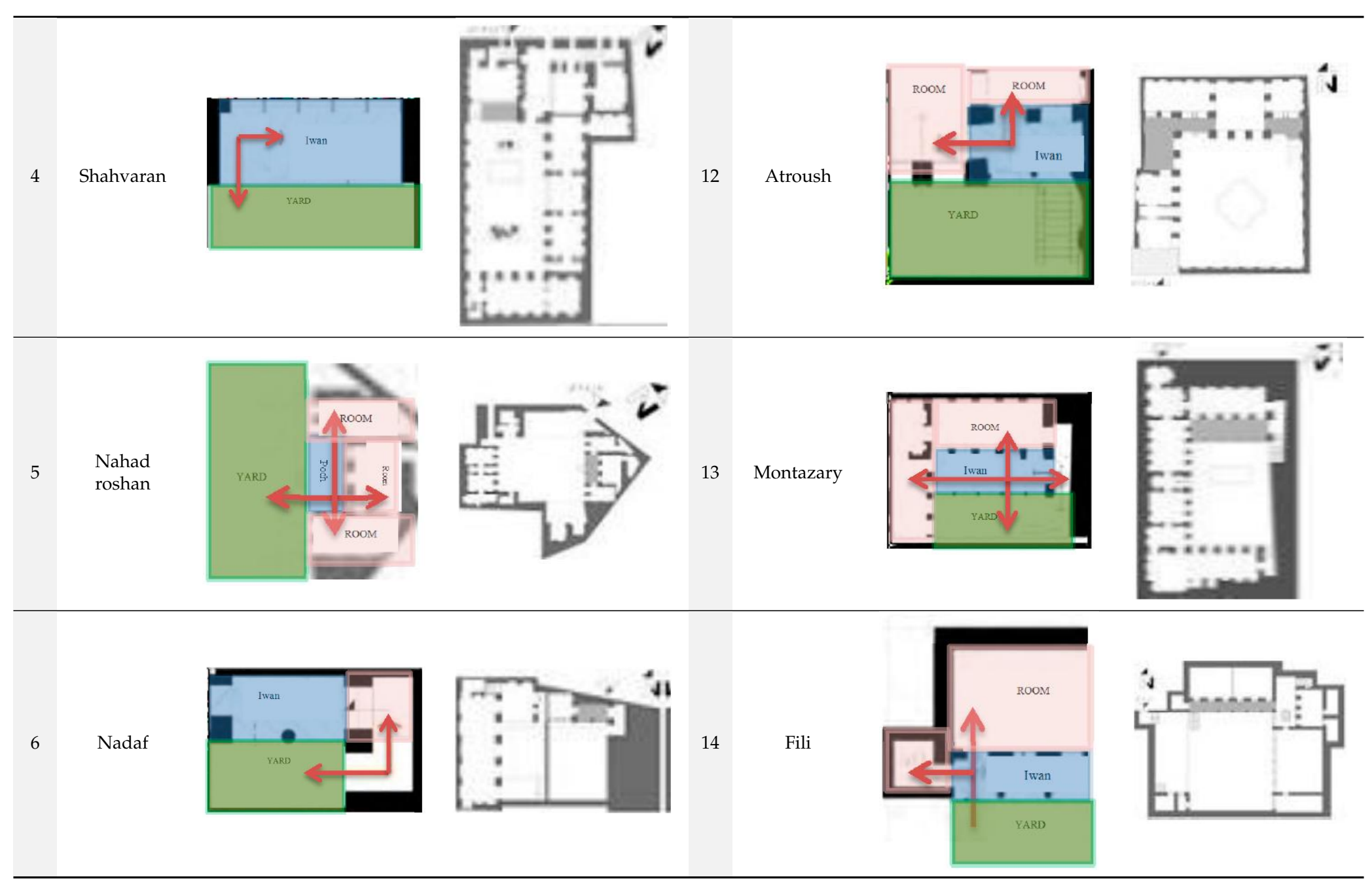


Table 2. Cont

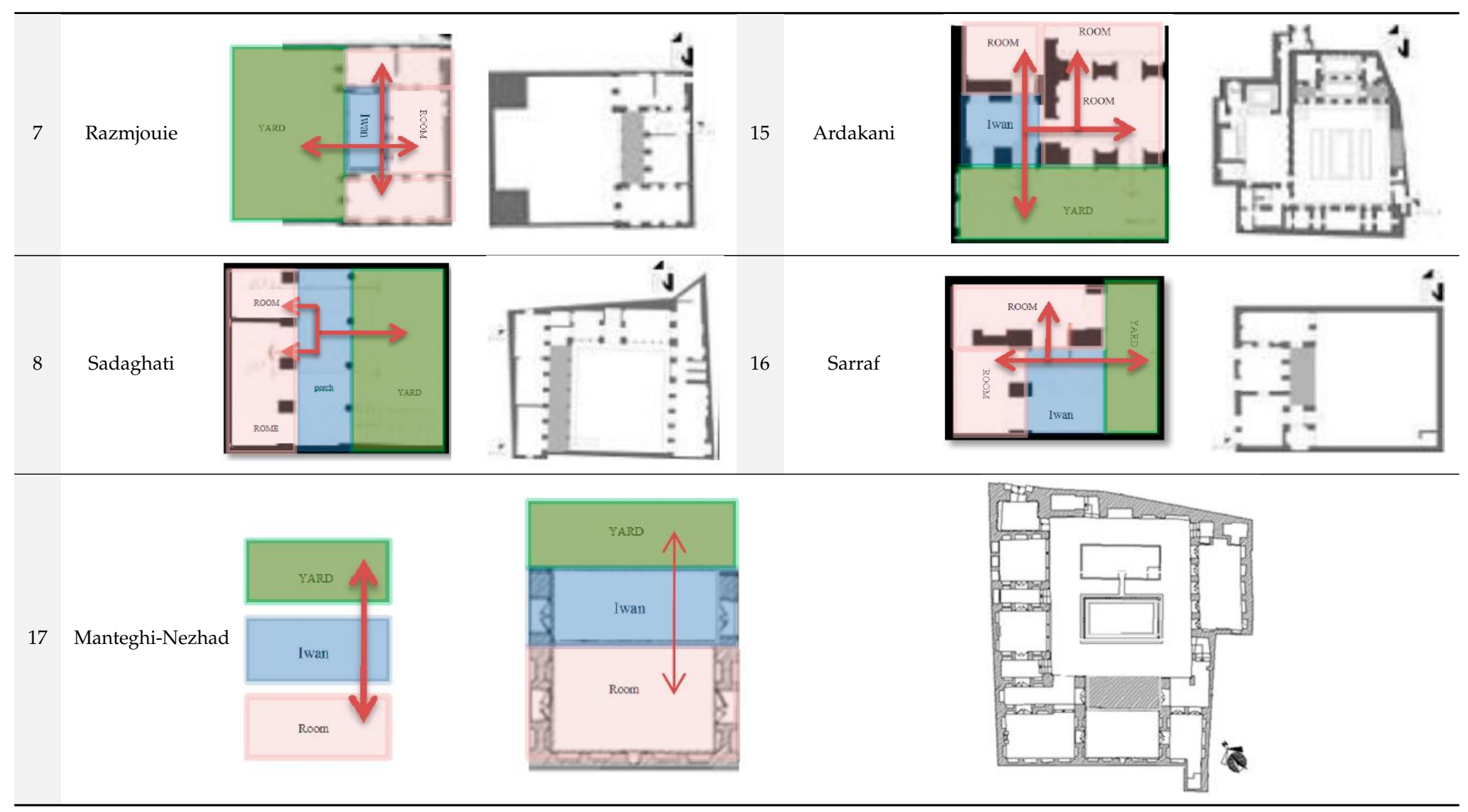


The talar room is placed at the back of the iwan, which is a considerable space in the building. The room has grille windows which are made of stone and glass, equipped with sashes capable of opening and closing the windows. It has doors that connect to rooms on both sides. The plan of the ground floor and underground sections of the house are shown in Figure 4, in which the place of the iwan and talar room in ground floor are marked by the hatched area.
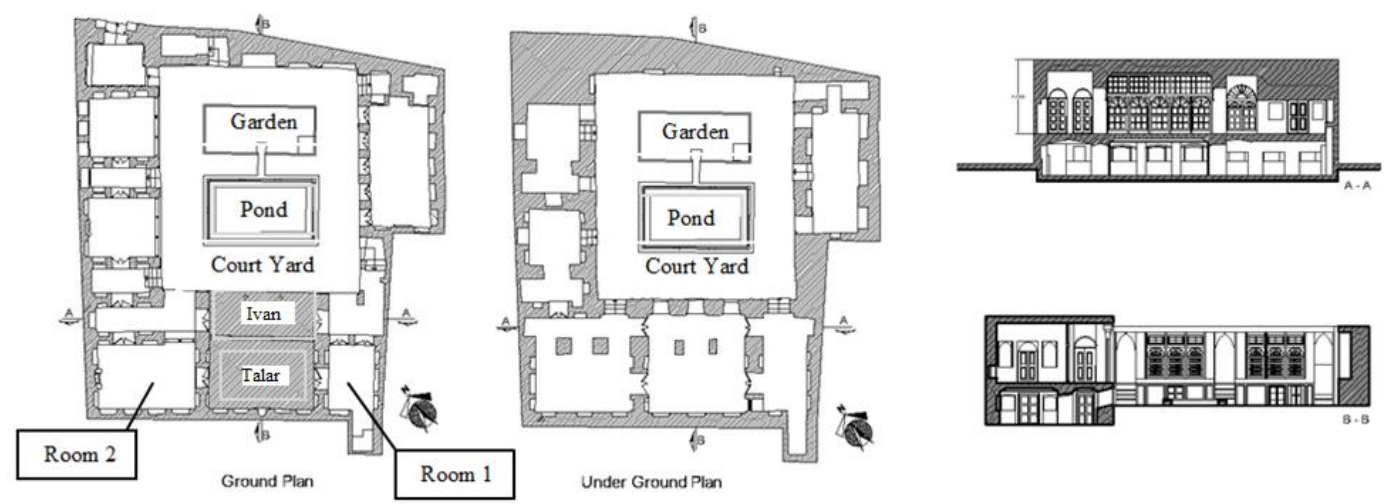

Figure 4. Plans of the underground floor and ground floor of the Manteghi-Nezhad house and the sections of the talar room and iwan.

\section{Microclimate Study}

Shiraz is located between $29.39^{\circ}$ north latitude and $52.35^{\circ}$ east longitude. According to Figure 5 , the climate of Shiraz is hot and dry. Shiraz is situated $1486 \mathrm{~m}$ above sea level. The monthly normal climate of Shiraz is given in Table 3. Based on Table 3, June, July, August, and September are the warmest months of the year.

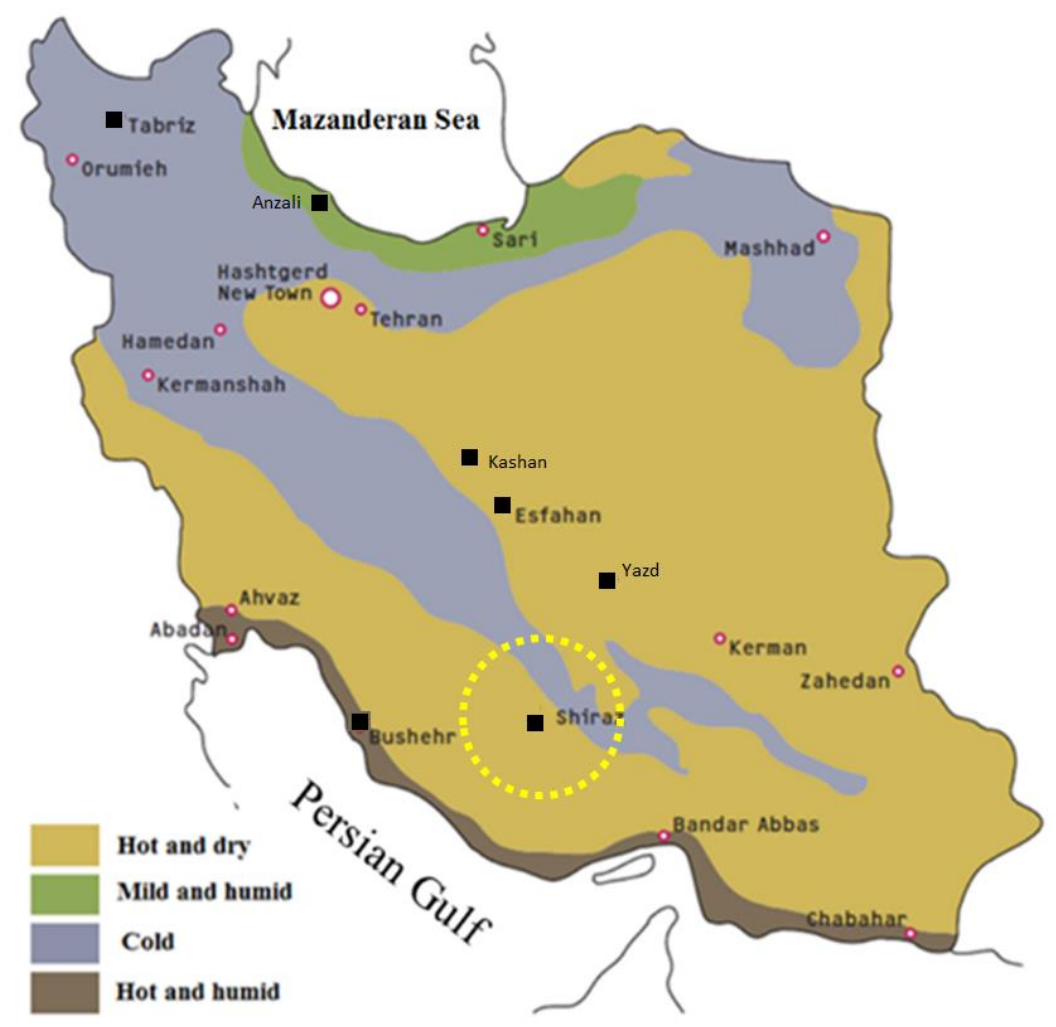

Figure 5. Climate divisions of Iran [42]. 
Table 3. Average weather conditions in Shiraz, Iran (2000-2016) (from the Meteorological Organization of Iran).

\begin{tabular}{|c|c|c|c|c|c|c|c|c|}
\hline Month & $\begin{array}{c}\text { Average Dry } \\
\text { Bulb Temp. }\left({ }^{\circ} \mathrm{C}\right)\end{array}$ & $\begin{array}{c}\text { Min Average } \\
\text { Dry Bulb Temp. }\left({ }^{\circ} \mathrm{C}\right)\end{array}$ & $\begin{array}{c}\text { Max Average } \\
\text { Dry Bulb Temp. }\left({ }^{\circ} \mathrm{C}\right)\end{array}$ & $\begin{array}{c}\text { Average } \\
\text { Relative } \\
\text { Humidity (\%) }\end{array}$ & $\begin{array}{c}\text { Min Average } \\
\text { Relative } \\
\text { Humidity (\%) }\end{array}$ & $\begin{array}{c}\text { Max Average } \\
\text { Relative } \\
\text { Humidity (\%) }\end{array}$ & $\begin{array}{c}\text { Average } \\
\text { Wind } \\
\text { Speed }(\mathrm{m} / \mathrm{s})\end{array}$ & $\begin{array}{c}\text { Average } \\
\text { Wind Speed } \\
\text { Direction (Degrees) }\end{array}$ \\
\hline January & 6 & 0 & 12 & 62 & 35 & 86 & 1.3 & 117 \\
\hline February & 7 & 1 & 13 & 57 & 33 & 82 & 2.2 & 136 \\
\hline March & 12 & 5 & 18 & 48 & 27 & 71 & 2.3 & 144 \\
\hline April & 17 & 9 & 24 & 40 & 23 & 61 & 2.8 & 171 \\
\hline I- May & $-\frac{23}{28}--$ & $--\frac{15}{19}---$ & $---\frac{30}{36}--$ & $-\frac{29}{19}--$ & $--\frac{16}{9}-$ & $--\frac{46}{34}--$ & $--\frac{3.3}{2.7}$ & $---\frac{198}{179}--_{\text {| }}$ \\
\hline July & 30 & 21 & 37 & 22 & 13 & 36 & 2.9 & 182 \\
\hline August & 29 & 20 & 37 & 24 & 11 & 40 & 2.4 & 155 \\
\hline September & $\frac{25}{19}--$ & $-\frac{14}{9}---$ & $-\frac{34}{27}---$ & $--\frac{23}{31}=$ & $-\frac{9}{11}--$ & $--\frac{42}{57}$ & -1.7 & $\left.---\frac{111}{126}--\right\rfloor$ \\
\hline November & 13 & 5 & 21 & 41 & 20 & 60 & 1.3 & 112 \\
\hline December & 6 & 1 & 13 & 61 & 38 & 82 & 1.7 & 110 \\
\hline
\end{tabular}




\section{Numerical Simulation}

DesignBuilder software [43] with the Energy Plus engine was used for the simulation of the Manteghi-Nezhad house. The thermal exchange between the spaces of the building, iwan, talar, and surrounding rooms were simulated. Also, the adjacent buildings which contribute to creating shade were considered as block components and some parts of the neighboring houses and underground spaces below the talar and surrounding rooms were assumed to be adiabatic. Two scenarios were simulated using this software. In the first case, the current situation was simulated according to Figure 6. In the second case, the talar was considered without the iwan, as shown in Figure 7.

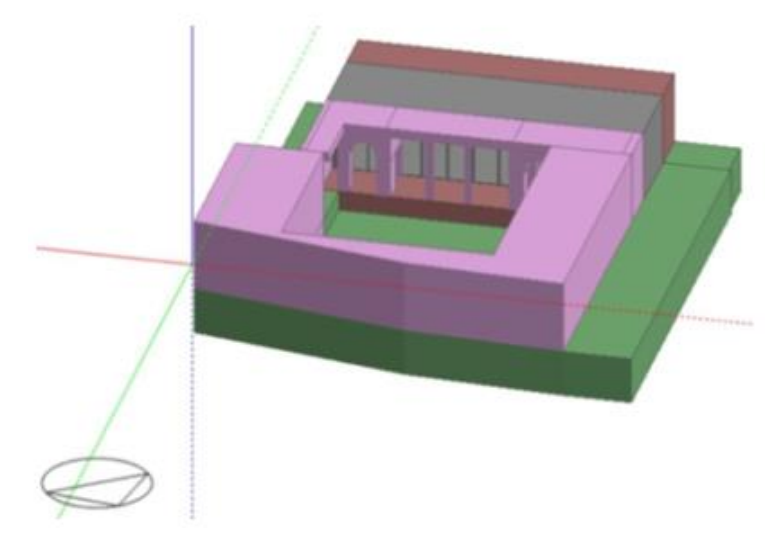

Figure 6. Simulation of the talar with an iwan (case 1).

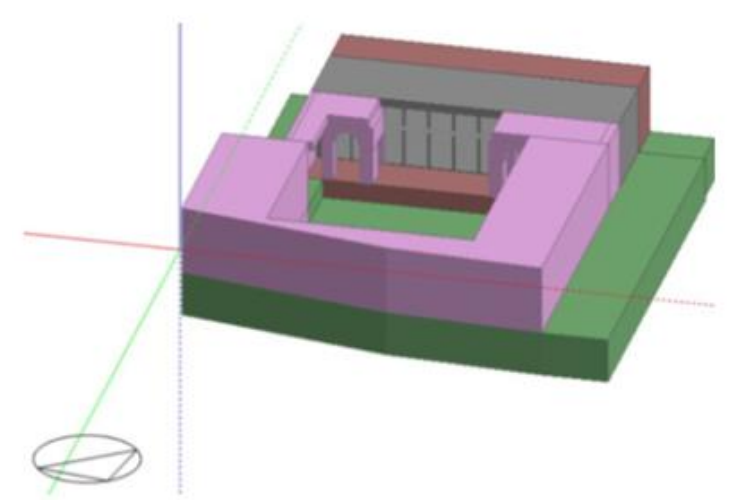

Figure 7. Simulation of the talar without an iwan (case 2).

The exterior and interior walls and roof of the building, which were made of traditional materials, were simulated by the DesignBuilder software based on layers with the current status. In Table 4, forms of the layers, the thickness and density of their material, their specific heat, and their thermal conductivity are presented.

The doors and frames of the windows and sashes are made of wood and the windows above the doors are made of common glass with a thickness of $3 \mathrm{~mm}$. To find the extent to which the iwan passively affects the environment of the talar room in a normal situation, no heating or cooling system was considered for the talar and surrounding rooms in the software. Ventilation was considered normally. The number of persons using the talar room was considered as the average number of members in an Iranian family, four people [44], and other rooms such as bedrooms were considered to have a one-person capacity. Detailed information is presented in Table 5. 
Table 4. Layers of floors, external wall, and internal wall in DesignBuilder software (National Building Regulations of Iran Building Code under the appellation of Issue 19, 2010 third edition building and housing research center publishing).

\begin{tabular}{|c|c|c|c|c|c|c|}
\hline $\begin{array}{l}\text { Detail of Wall } \\
\text { and Floor }\end{array}$ & $\begin{array}{c}\text { Number } \\
\text { of Layers }\end{array}$ & Layer & $\begin{array}{l}\text { Thickness } \\
\text { (m) }\end{array}$ & $\begin{array}{l}\text { Conductivity } \\
\text { (W/m-K) }\end{array}$ & $\begin{array}{c}\text { Specific Heat } \\
(\mathrm{j} / \mathrm{kg}-\mathrm{K})\end{array}$ & $\begin{array}{l}\text { Density } \\
\left(\mathrm{kg} / \mathrm{m}^{3}\right)\end{array}$ \\
\hline \multirow{3}{*}{ External wall } & \multirow{3}{*}{3} & Plaster & 0.01 & 0.4 & 1000 & 1000 \\
\hline & & Brick & 0.47 & 0.72 & 840 & 1920 \\
\hline & & Plaster & 0.02 & 0.4 & 1000 & 1000 \\
\hline \multirow{3}{*}{ Internal wall } & \multirow{3}{*}{3} & Plaster & 0.02 & 0.4 & 100 & 1000 \\
\hline & & Adobe & 0.06 & 1.1 & 840 & 1770 \\
\hline & & Plaster & 0.02 & 0.4 & 1000 & 1000 \\
\hline \multirow{7}{*}{ Floor } & \multirow{7}{*}{7} & Thatch & 0.01 & 1.1 & 840 & 1500 \\
\hline & & Soil & 0.02 & 1.1 & 840 & 1770 \\
\hline & & Ghoureh- ${ }^{1}$ gel & 0.12 & 1.1 & 840 & 1770 \\
\hline & & Mat & 0.003 & 0.19 & 2390 & 700 \\
\hline & & Wood Timber & 0.03 & 0.19 & 2390 & 700 \\
\hline & & Air & 0.3 & - & - & - \\
\hline & & Lathing & 0.02 & 0.19 & 2390 & 700 \\
\hline
\end{tabular}

${ }^{1}$ A kind of concrete that is used in the slope of roofs; instead of limestone, gypsum and debris are used.

Table 5. Occupied area of rooms in DesignBuilder software.

\begin{tabular}{cccc}
\hline Name of Room & Area $\left(\mathbf{m}^{\mathbf{2}}\right)$ & Number of People & Density $($ People/m $\mathbf{2})$ \\
\hline Talar & 24.54 & 4 & 0.163 \\
Room 1 & 11.73 & 1 & 0.085 \\
Room 2 & 22.13 & 1 & 0.045 \\
\hline
\end{tabular}

\section{Validation}

For the validation of the DesignBuilder simulation software, information related to temperature and relative humidity were collected from 9:00 a.m. on 24 January 2017 to 9:00 a.m. on 2 February 2017 (10 days). This period included the coldest days during 2017 according the meteorological organization of Iran. The interval time for the data collection was $20 \mathrm{~min}$. The location of the data logger is shown in Figure 8. The measurement was taken in the center of the talar room and the data logger's height was $0.8 \mathrm{~m}$.

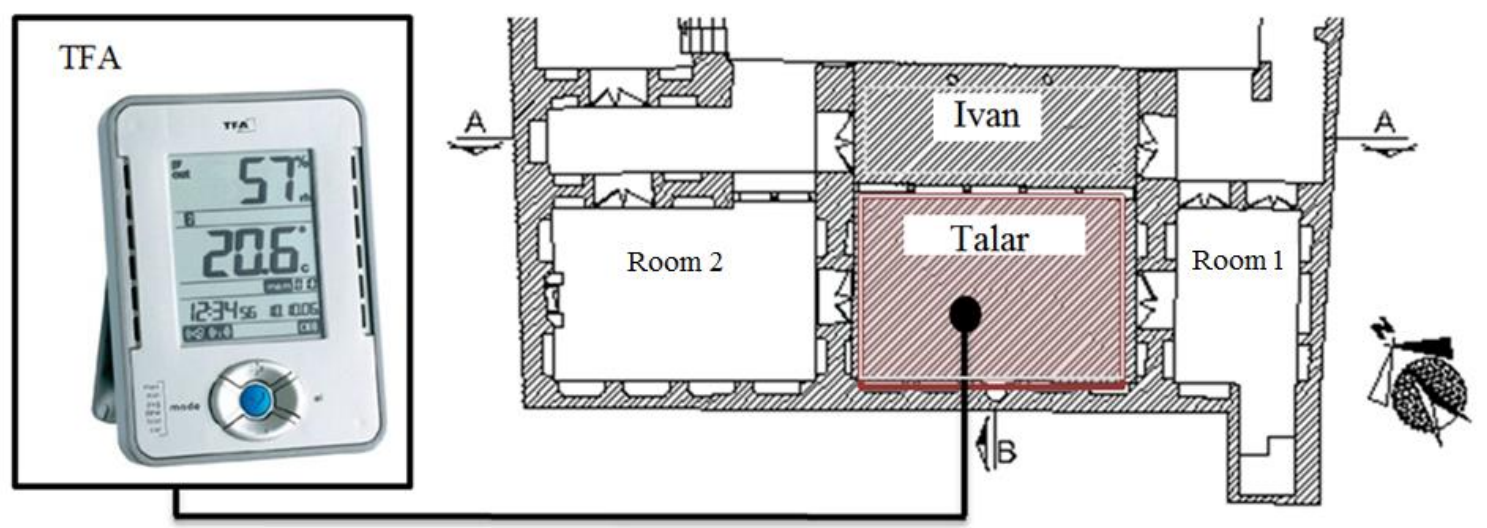

Figure 8. Data logger for recording air temperature and humidity, as well as its the location in the talar room.

The accuracy of the data logger device in measuring the temperature was $\pm 0.5^{\circ} \mathrm{C}$ and its accuracy in measuring the relative humidity was $3 \%$ for temperatures between -30 and $+70{ }^{\circ} \mathrm{C}$. It had the 
capacity to connect to a computer and data could be transferred to a PC. This data logger connected to computer as PC and it do not connect to laptop. After collecting related field data, they were compared to software data for the same period of time. Variation of temperature and relative humidity for the mentioned period is illustrated in Figure 9.

According to Figure 9, the difference between the field data and simulation for temperature was $1.7 \%$, which was in an acceptable range. Also, the difference between the field data and simulation for relative humidity was $3.8 \%$. Based on the agreements, the results of the thermal performance of the talar room using the software are calculated in the next section.
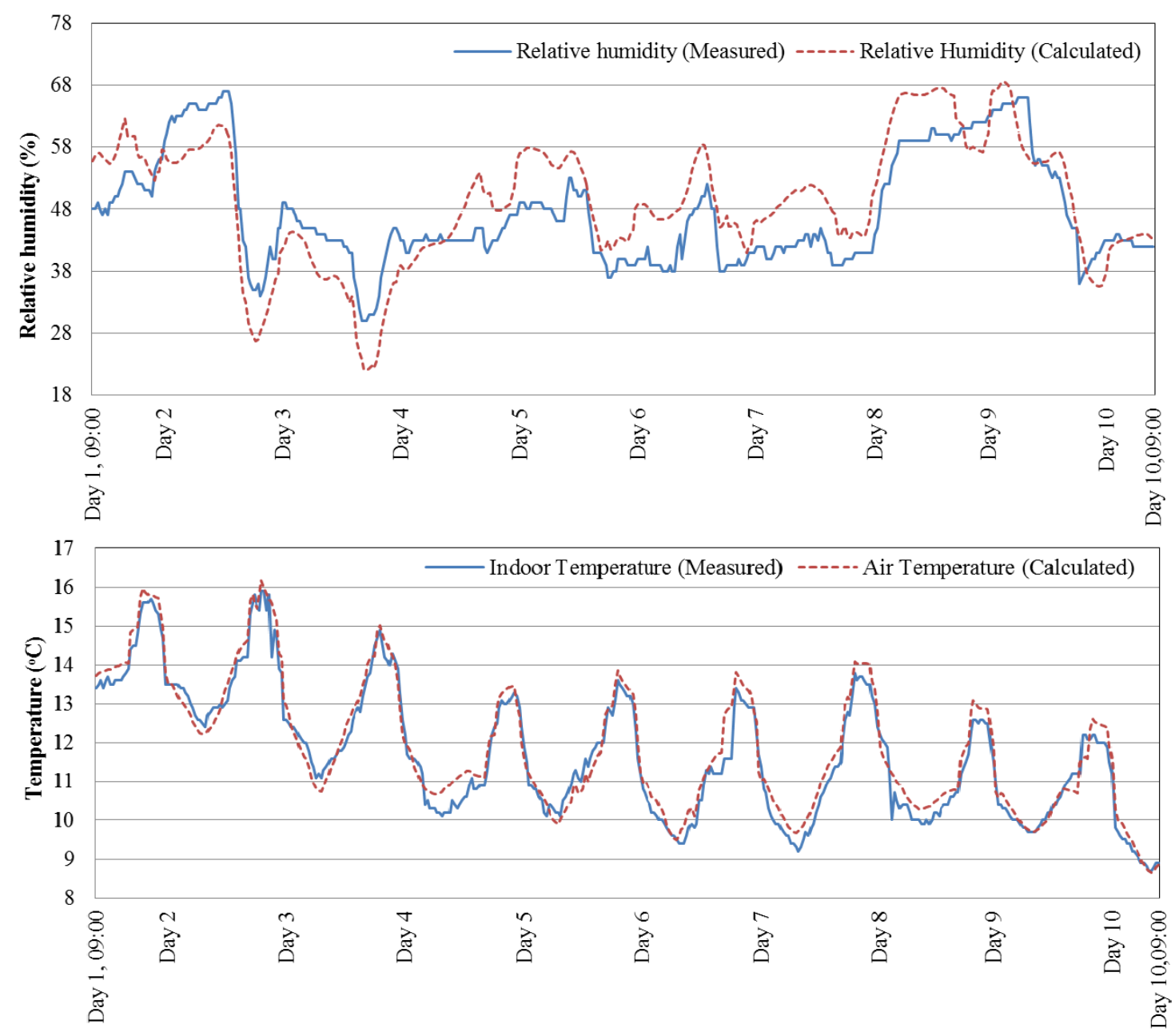

Figure 9. Comparison of the measured temperature, relative humidity and calculated temperature, relative humidity for the central talar room (24 January 09:00 a.m. to 2 February 09:00 a.m., 2017).

\section{Discussion}

In this section, data related to simulation scenarios of the talar room at the Manteghi-Nezhad house in the two cases of considering the talar with an iwan and without an iwan are represented. In Figure 10, the air temperature $\left(T_{a}\right)$, radiant temperature $\left(T_{r}\right)$, and relative humidity of the talar room with the iwan and without the iwan are illustrated over one year in order to distinguish the performance of the iwan during warm and cold months.

The indoor temperature and radiant temperature of both cases were less than the outdoor dry bulb temperature in the warm months (according Table 3, the warm months are June, July, August, and September). Furthermore, in the cold months $\mathrm{T}_{\mathrm{a}}$ and $\mathrm{T}_{\mathrm{r}}$ were higher than the outdoor dry bulb temperature. This was due to the materials of the house, which responded well in both warm and cold 
months. The figure shows that the indoor temperature and radiant temperature of both cases were less than the outdoor dry bulb temperature in the warm months. This was because of the talar room, which was located on the south side of the courtyard with the backside towards the sun and with sufficient shadow. In the warm months, the average air temperature of the talar room with the iwan was $2.3^{\circ} \mathrm{C}$ less than the outdoor temperature but the average $\mathrm{T}_{\mathrm{a}}$ of the talar room without the iwan was $1.2^{\circ} \mathrm{C}$.

Furthermore, the average difference of $\mathrm{T}_{\mathrm{r}}$ for the talar room with the iwan in comparison to the talar room without the iwan was $0.4{ }^{\circ} \mathrm{C}$. This is because more shadows were provided by the iwan. However, in the cold months, the average of air temperature of the talar room without the iwan was $2.3^{\circ} \mathrm{C}$ higher than the outdoor temperature, but average of $\mathrm{T}_{\mathrm{a}}$ of the talar room with the iwan was $1.7^{\circ} \mathrm{C}$ higher than the outdoor temperature because the talar room without the iwan receives more sun radiation.

Figure 10 illustrates that the talar room had the lowest relative humidity during the warm months, lower than 20\%. The relative humidity in January, February, and December was higher compared to other months of the year as it was higher than $40 \%$.
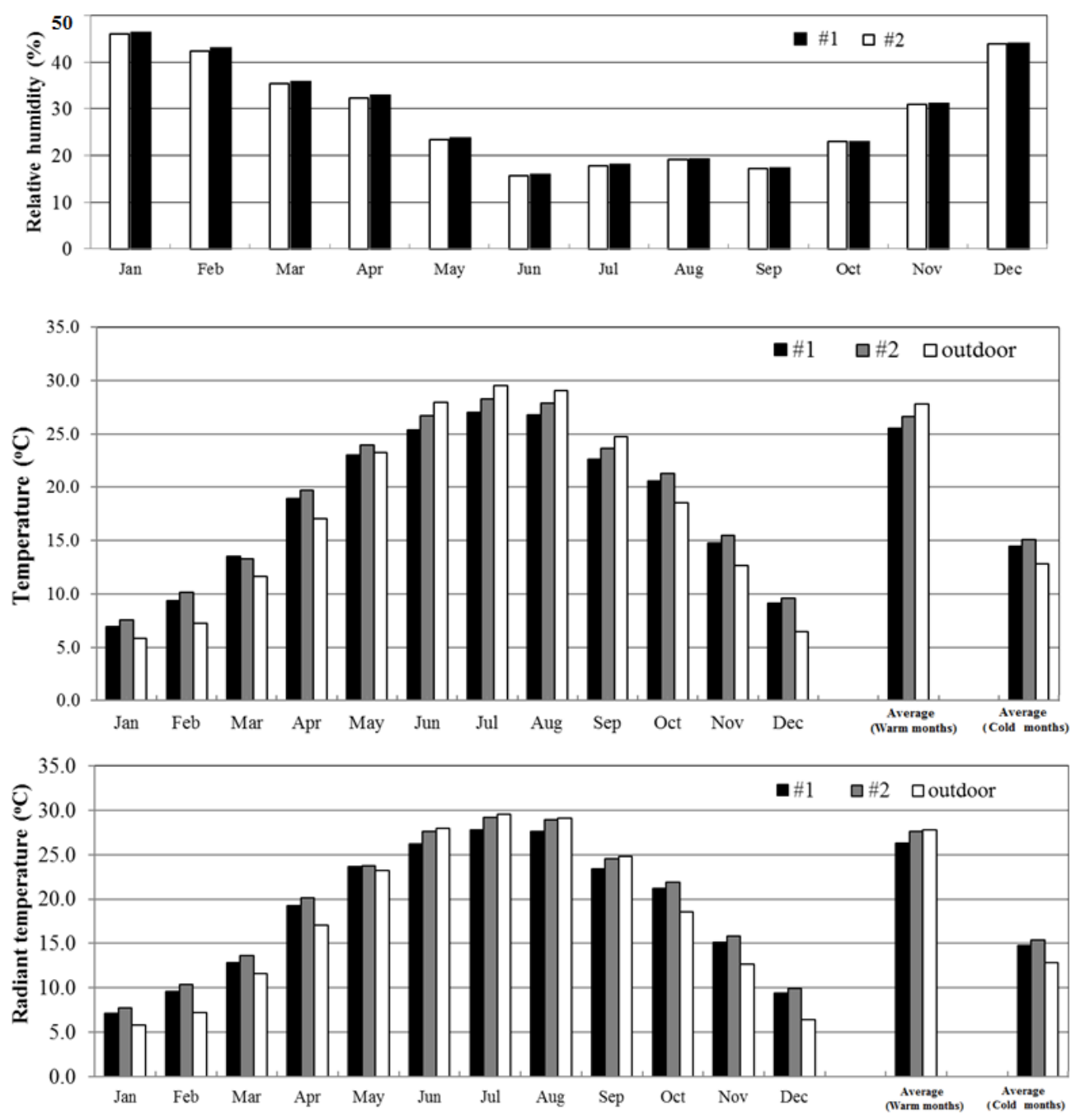

Figure 10. Comparison of the average temperature, radiant temperature, and relative humidity of the talar room for case 1 and case 2 during different months.

After the analysis of air temperature, mean radiant temperature (MRT) wind speed, and relative humidity, the value of the PMV and PPD were calculated according Equations (1) and (2), as represented in Figure 11. The metabolic rate for calculated PMV and PPD was assumed to be 0.9 . 
The metabolic rate is the average of light working, seating, relaxing, sleeping, and reclining according to ISO 7730 [41]. Also, the clothing level was assumed to be 0.5 according to ISO 7730 [41] for typical summer indoor clothing.

According to previous studies, thermal comfort can be evaluated by the PMV index. Figure 11 shows the variation of the PMV of the talar room for the two cases-with an iwan and without an iwan. Based on Figure 11, the thermal sensitivity of the talar room in both cases in January, February, and December was cold. The PMV index in May, June, September, and October was nearly zero, which was very appropriate, and the thermal sensitivity of July and August was slightly warm. For case 1 in the warm months, the PMV index was less than that of case 2. Also, the PMV of case 2 was less than that of case 1 in the cold months. The difference of the PMV index between cases 1 and 2 was $2.8 \%$ because of the different air temperature and radiant temperature values, which are shown in Figure 10.

According to the PMV index, the PPD can be calculated. Figure 11 shows the percentage of dissatisfaction of the residents in the talar for both cases during various months. It can be seen that during warm months the PPD index was lower than that during cold months. The lowest value of the dissatisfaction index belongs to May, June, July, September, and October, being less than $25 \%$. For the talar room with an iwan, this shows that in warm months the PPD was reduced.

It must be noted that, in reality, in Manteghi-Nezhad house, the talar room with a $\mathrm{v}$ form was used during the warm months. According to Figure 11, the iwan was an important element for achieving thermal comfort in the talar room during the warm months.

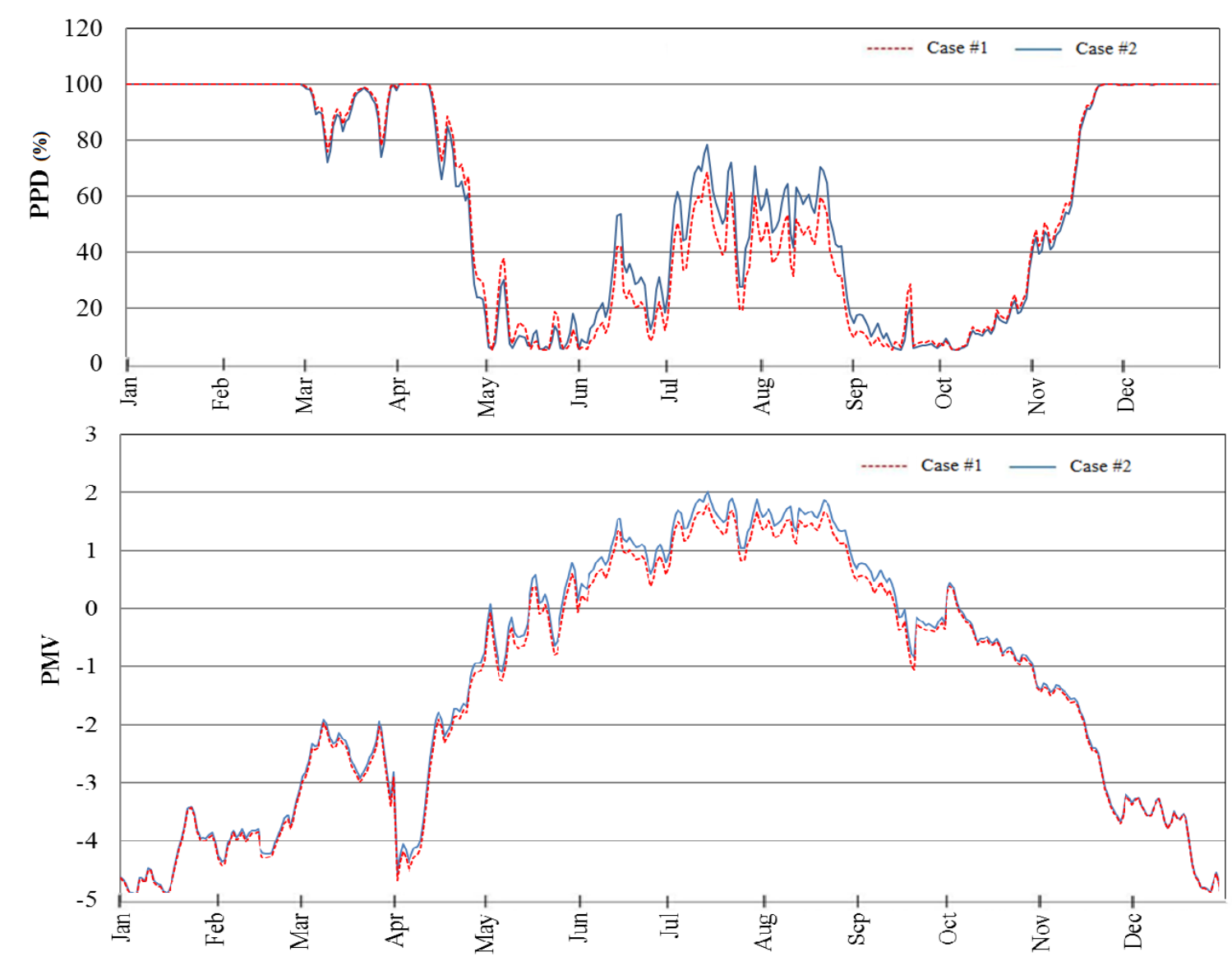

Figure 11. Annual variation of PMV and PPD of the talar room with for case 1 and case 2.

The monthly averages of the PMV and PPD indexes in both cases during the warm months (June to September) are shown in Figure 12. As shown, the PMV of case 1 was 0.5 less than the PMV of case 2 in July, August, September, and October, whereas it provided comfortable conditions for the 
occupants. Based on Figure 12, the difference between the PMV index of the talar room with an iwan and that without an iwan was $62.5 \%$.

The average PPD index of the talar for the two cases during the warm months is presented in Figure 12. The results show that dissatisfaction rate of case 1 was less than that of case 2 during the warm months. The PPD of the talar room with an iwan decreased by $14 \%$ in comparison with the talar room without an iwan.

The relevant values of PMV and PPD of the talar room with an iwan ascertained that the good performance of the iwan could create more shadows. Thus, the iwan in the south orientation of the courtyard is an effective element in the Manteghi-Nezhad house to reduce heat, especially during the warm months.
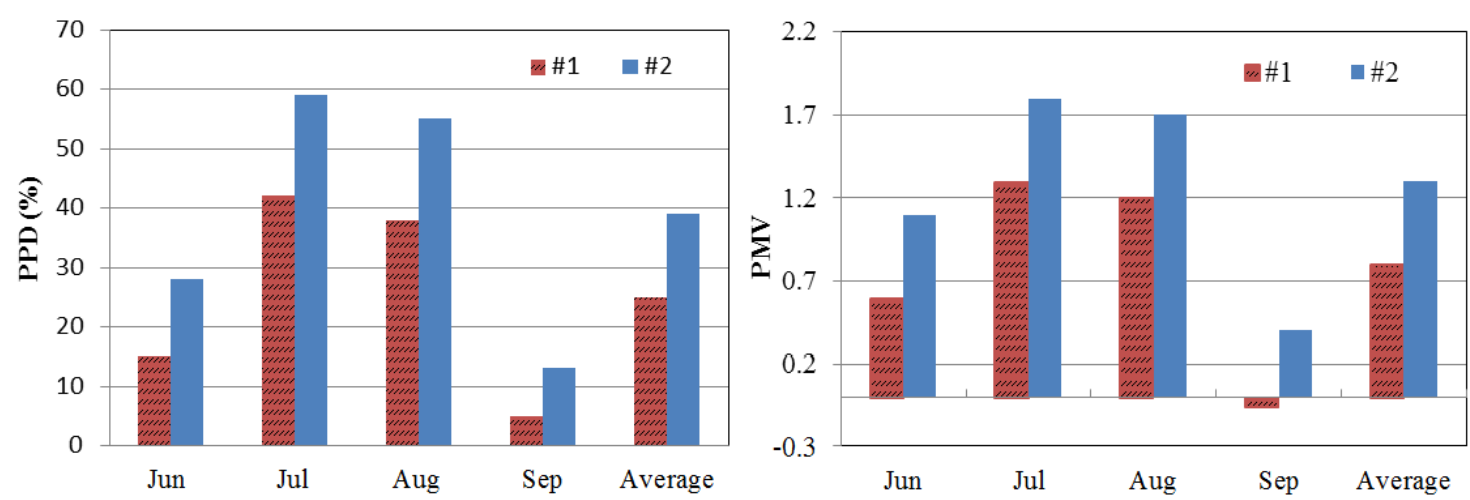

Figure 12. Comparison of PMV and PPD of the talar room for cases 1 and 2 during the warm months.

In order to analyze the indoor air temperature, relative humidity, and radiant air temperature in detail, a representative day during the hot months was selected. According to Figure 13, the selected variables were compared for case 1 and case 2 to find out the overall thermal conditions that the iwan can provide inside the talar room. The results of indoor air temperature and radiant air temperature showed that the iwan could significantly affect the overall indoor conditions in case 1 . The difference between the indoor air temperature and the outdoor air temperature in the afternoon was measured as the highest value for the talar with the iwan. The indoor air temperature at 4:00 p.m. was $36^{\circ} \mathrm{C}$ while the outdoor air temperature was more than $41^{\circ} \mathrm{C}$. The difference for radiant air temperature was higher than the indoor air temperature, where it rose up to $6{ }^{\circ} \mathrm{C}$ at 4:00 p.m. This was due to the shadow caused by the iwan projection at the southern direction of house. Comparison of the results during the nighttime and the early morning showed a small difference between the indoor and outdoor air temperatures in both cases. This was due to the absence of sun radiation. Even the difference of air temperature between cases 1 and 2 was less than $1{ }^{\circ} \mathrm{C}$. This shows that the iwan could effectively reduce the air temperature as well as the radiant air temperature during the morning and the afternoon times.

According to Figure 13, the relative humidity in both cases was between $17 \%$ and $29 \%$ and the difference was trivial. Thus, it can be declared that the iwan could not affect relative humidity in the indoor environment. According to the results, the relative humidity in the evening was higher than that in early morning. This was due to the evaporation of water in the courtyard, especially in the afternoon when the solar radiation was intensive.

Table 6 presents the comparison between different air temperatures, the PMV, and the PPD for both cases in a representative day. According to the results, the maximum difference between the air temperature and radiant air temperature of cases 1 and 2 occurred at 3:00 p.m. in the afternoon. The results show that iwan could decrease the indoor air temperature up to $3{ }^{\circ} \mathrm{C}$ where the same amount of solar radiation was received in the afternoon. The average indoor air temperature and radiant air temperature for $24 \mathrm{~h}$ indicates that the talar with the iwan could provide a better temperature in comparison with the talar without the iwan. The difference between air temperatures was more 
than $1^{\circ} \mathrm{C}$ through the day. As a consequence, the PMV for case 1 was 1.1 , which was better than case 2 with a PMV of 1.3. The Predicted Percentage of Dissatisfaction (PPD) for both cases showed that case 1 with the iwan had better thermal condition in $24 \mathrm{~h}$. Based on the results, the PPD in case 1 was $9 \%$ less than that for case 2 .
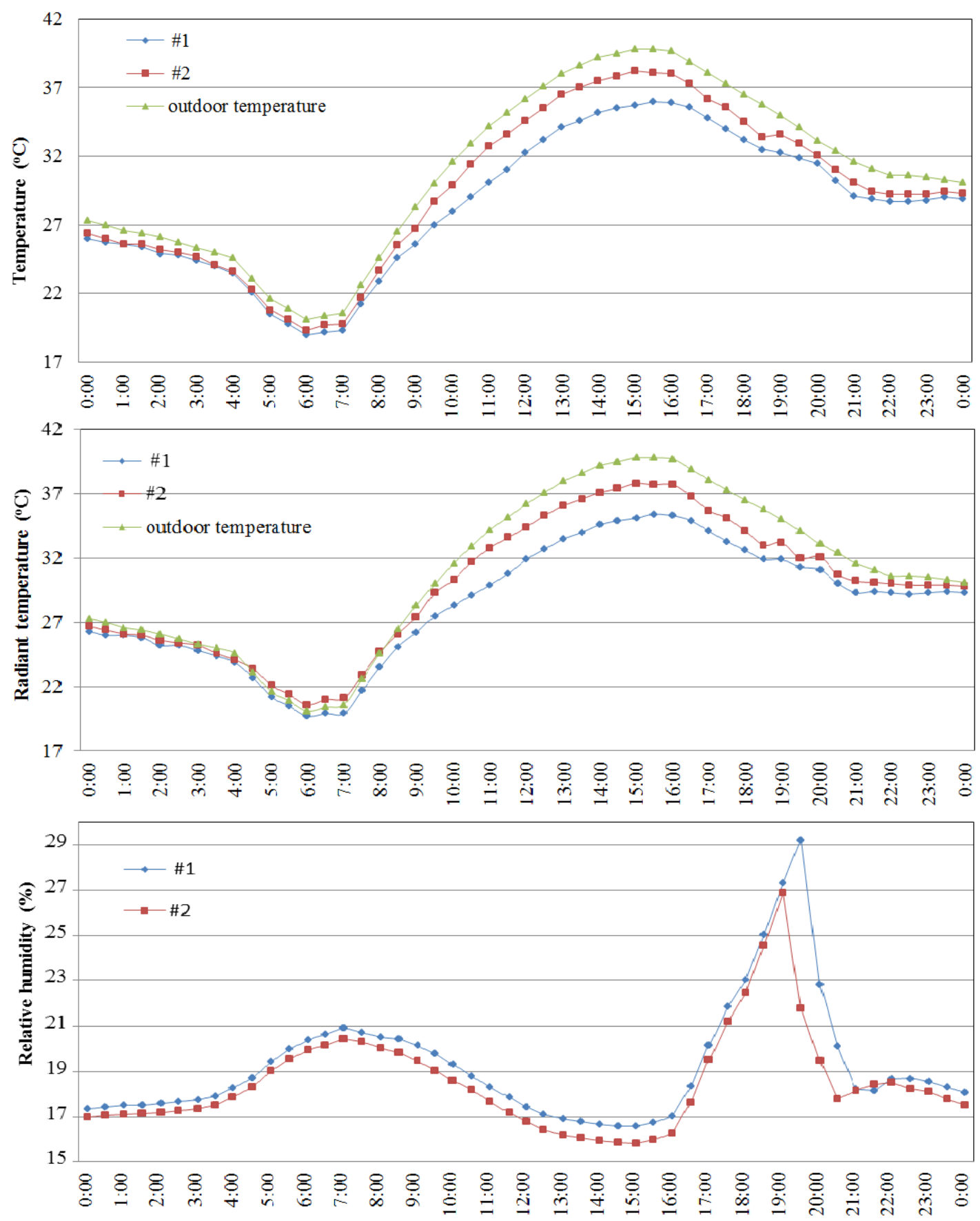

Figure 13. Comparison of the air temperature, radiant temperature, and relative humidity of the talar room for cases 1 and 2 on 29 July, Shiraz, Iran.

Comparison of results for the selected scenarios ascertain that the iwan as an architectural element in traditional houses could significantly reduce indoor air temperature and radiant temperature, especially in the afternoon when a high amount of solar radiation penetrates the buildings. As a result, better thermal comfort can be achieved according to the results of PMV and PPD for the current study. 
Thus, this study recommends further studies on the implementation of iwans in the new development of housing in the same microclimate for the provision of better thermal conditions as well as for saving energy in residential buildings.

Table 6. Comparison of average thermal conditions of the talar room for cases 1 and 2 on 29 July, Shiraz, Iran.

\begin{tabular}{|c|c|c|c|c|c|}
\hline $\begin{array}{l}\text { Thermal } \\
\text { Conditions }\end{array}$ & Case & 3:00 p.m. & $\begin{array}{l}\text { Average 8:00 } \\
\text { a.m.-8:00 p.m. }\end{array}$ & $\begin{array}{l}\text { Average 12:00 } \\
\text { a.m.-8:00 a.m. }\end{array}$ & Average $24 \mathrm{~h}$ \\
\hline \multirow{2}{*}{$T_{a}\left(C^{o}\right)$} & 1 & 35.7 & 31.8 & 24.9 & 28.4 \\
\hline & 2 & 38.2 & 33.6 & 25.2 & 29.5 \\
\hline \multirow{2}{*}{$T_{r}\left(C^{0}\right)$} & 1 & 35.1 & 31.6 & 25.4 & 28.5 \\
\hline & 2 & 37.8 & 33.5 & 26 & 29.8 \\
\hline \multicolumn{2}{|c|}{$\mathrm{T}_{\text {outdoor }}\left({ }^{\circ} \mathrm{C}\right)$} & 39.8 & 35.3 & 26.3 & 30.8 \\
\hline \multirow{2}{*}{ PMV } & 1 & 2.9 & 1.8 & -0.09 & 1.1 \\
\hline & 2 & 3.8 & 2.39 & 0.03 & 1.3 \\
\hline \multirow{2}{*}{ PPD (\%) } & 1 & 100 & 67 & 5 & 32 \\
\hline & 2 & 100 & 91 & 5 & 41 \\
\hline
\end{tabular}

\section{Conclusions}

The iwan has been used in hot and dry climates in many traditional houses in different forms and with various materials. The thermal comfort of a talar in a traditional house in Shiraz was studied for the two cases of the adjoined iwan with and without iwan. According to the results of field measurements and simulations, the following outcomes are specified.

(1) The average indoor temperature of the talar during the year was about $3.9^{\circ} \mathrm{C}$ higher than the outdoor temperature in the case of the iwan with a ceiling. The indoor temperature of the talar room with an iwan without a ceiling was $1 \%$ higher than that of the talar room with the iwan having ceiling over the course of one year. The difference between radiant and operative temperature in the two cases was very low.

(2) The relative humidity in the talar room in both cases was below $20 \%$ in June, July, August, and September, while it was between $20 \%$ and $40 \%$ in October, November, March, April, and May. The relative humidity of the talar room in January, February, and December was higher than $40 \%$.

(3) The talar in the case of the iwan with a ceiling was completely appropriate to fulfill the thermal comfort situation in June, July, September, and October. Furthermore, in August and September, it was in the range of warm and in December it was relatively cool. It was not under the comfort range in other months of the year, although a heating device was necessary. In the case of the iwan without a ceiling, the situation was not in the comfort range, especially in the summer months. However, the conditions improved slightly in the cold months.

(4) Based on the calculated PMV index, the talar with the iwan without a ceiling was $8 \%$ better during the year, but for warm months the talar with the iwan with a ceiling was $42 \%$ better than the talar with the iwan without a ceiling.

(5) In terms of the PPD index, the dissatisfaction rate in the case of the iwan with a ceiling was below $20 \%$ in June, July, September, and October, while the dissatisfaction index was about $40 \%$ in the two months of August and September. The dissatisfaction rate was poor for the cold months of the year. The PPD for the talar with an iwan with a ceiling was $18 \%$ better than that for the iwan without a ceiling during warm months.

(6) The analyses of indoor thermal conditions for a representative day ascertained that the case with the iwan could significantly reduce the indoor air temperature. According to the results, the difference of indoor air temperature between the selected scenarios reached up to $3^{\circ} \mathrm{C}$ in the afternoon, when high amount of solar intensity hit the building. 
(7) According to the results, the iwan contributes to the thermal satisfaction inside traditional buildings. Thus, it is recommended that further studies be carried out in order to apply this architectural element to the development of new residential buildings for the same microclimate.

Author Contributions: Conceptualization, J.S.; Methodology, J.S.; Software, J.S.; Validation, M.Y., A.H.; Formal Analysis, J.S.; Investigation J.S., M.Y., A.H.; Resources, M.Y., A.H.; Data Curation, J.S., M.Y., A.H.; Writing-Original Draft Preparation, J.S., M.Y., A.H.; Writing-Review \& Editing, M.Y., A.H.; Visualization, J.S.; Supervision, M.Y., A.H., Project Administration, J.S.

Funding: This research received no external funding

Conflicts of Interest: The authors declare no conflicts of interest.

\section{References}

1. Afshari, H. Design Fundamentals in the Hot and Humid Climate of Iran: The Case of Khoramshahr. Asian Cult. Hist. 2012, 4, 65. [CrossRef]

2. Bodach, S.; Lang, W.; Hamhaber, J. Climate responsive building design strategies of vernacular architecture in Nepal. Energy Build. 2014, 81, 227-242. [CrossRef]

3. Chávez, J.R.G.; Melchor, F.F. Application of Combined Passive Cooling and Passive Heating Techniques to Achieve Thermal Comfort in a Hot Dry Climate. Energy Procedia 2014, 57, 1669-1676. [CrossRef]

4. Sarkar, A. Study of Climate Responsive Passive Design Features in Traditional Hill Architecture of Khyah Village in Hamirpur, Himachal Pradesh, India Indoor Thermal Comfort. J. Inst. Eng. Ser. A 2013, 94, 59-72. [CrossRef]

5. Singh, M.K.; Mahapatra, S.; Atreya, S.K. Bioclimatism and vernacular architecture of north-east India. Build. Environ. 2009, 44, 878-888. [CrossRef]

6. Mashhadi, M.K. Comparison of Iranian and Turkish Traditional Architectures in Hot-Dry Climates, Eastern Mediterranean University (EMU). 2012. Available online: http:/ /hdl.handle.net/11129/108 (accessed on 2 June 2018).

7. Baran, M.; Yıldırım, M.; Yılmaz, A. Evaluation of ecological design strategies in traditional houses in Diyarbakir, Turkey. J. Clean. Prod. 2011, 19, 609-619. [CrossRef]

8. Nematchoua, M.K.; Tchinda, R.; Orosa, J.A. Thermal comfort and energy consumption in modern versus traditional buildings in Cameroon: A questionnaire-based statistical study. Appl. Energy 2014, 114, 687-699. [CrossRef]

9. Soleymanpour, R.; Parsaee, N.; Banaei, M. Climate Comfort Comparison of Vernacular and Contemporary Houses of Iran. Procedia Soc. Behav. Sci. 2015, 201, 49-61. [CrossRef]

10. Motealleh, P.; Zolfaghari, M.; Parsaee, M. Investigating climate responsive solutions in vernacular architecture of Bushehr city. HBRC J. 2016. [CrossRef]

11. Priya, R.S.; Sundarraja, M.C.; Radhakrishnan, S.; Vijayalakshmi, L. Solar passive techniques in the vernacular buildings of coastal regions in Nagapattinam, TamilNadu-India-A qualitative and quantitative analysis. Energy Build. 2012, 49, 50-61. [CrossRef]

12. Dili, A.S.; Naseer, M.A.; Varghese, T.Z. Passive environment control system of Kerala vernacular residential architecture for a comfortable indoor environment: A qualitative and quantitative analyses. Energy Build. 2010, 42, 917-927. [CrossRef]

13. Praseeda, K.I.; Mani, M.; Reddy, B.V.V. Assessing Impact of Material Transition and Thermal Comfort Models on Embodied and Operational Energy in Vernacular Dwellings (India). Energy Procedia 2014, 54, 342-351. [CrossRef]

14. Mehr, S.M.; Noghrekar, A.H.; Mozaffar, F.; Taghdir, S. Architectural Space Affordance of Iranian Traditional Houses in Response to Levels of Physical and Spiritual Human Needs. Procedia Soc. Behav. Sci. 2015, 201, 342-351. [CrossRef]

15. Mohammadabadi, M.A.; Ghoreshi, S. Green Architecture in clinical centres with an approach to Iranian sustainable vernacular architecture (Kashan City). Procedia Eng. 2011, 21, 580-590. [CrossRef]

16. Manioğlu, G.; Yılmaz, Z. Energy efficient design strategies in the hot dry area of Turkey. Build. Environ. 2008, 43, 1301-1309. [CrossRef] 
17. Soflaei, F.; Shokouhian, M.; Mofidi Shemirani, S.M. Traditional Iranian courtyards as microclimate modifiers by considering orientation, dimensions, and proportions. Front. Archit. Res. 2016, 225-238. [CrossRef]

18. Şerefhanoğlu Sözen, M.; Gedík, G.Z. Evaluation of traditional architecture in terms of building physics: Old Diyarbakír houses. Build. Environ. 2007, 42, 1810-1816. [CrossRef]

19. Sedighi, E.; Yaghoubi, M.; Mousavi, S.M.; Siahpour, S. Thermal study of domed roofs in a traditional bazaar (the case of old Ganj-Alikhan bazaar in Kerman, Iran). Energy Sustain. Dev. 2017, 39, 67-81. [CrossRef]

20. Saljoughinejad, S.; Sharifabad, R.S. Classification of climatic strategies, used in Iranian vernacular residences based on spatial constituent elements. Build. Environ. 2015, 92, 475-493. [CrossRef]

21. Foruzanmehr, A. People's perception of the loggia: A vernacular passive cooling system in Iranian architecture. Sustain. Cities Soc. 2015, 19, 61-67. [CrossRef]

22. Foruzanmehr, A. Thermal comfort and practicality: Separate winter and summer rooms in Iranian traditional houses. Archit. Sci. Rev. 2016, 59, 1-11. [CrossRef]

23. Atrvash, A.; Fayaz, R. The effect of orsis on the air in the interior (Case Study: Zinat almolk of shiraz). Archit. Urban Plan. 2015, 9, 19-26.

24. Ryu, Y.; Kim, S.; Lee, D. The influence of wind flows on thermal comfort in the Daechung of a traditional Korean house. Build. Environ. 2009, 44, 18-26. [CrossRef]

25. Al-Hinai, H.; Batty, W.J.; Probert, S.D. Vernacular architecture of Oman: Features that enhance thermal comfort achieved within buildings. Appl. Energy 1993, 44, 233-258. [CrossRef]

26. Saadatian, O.; Haw, L.C.; Sopian, K.; Sulaiman, M.Y. Review of windcatcher technologies. Renew. Sustain. Energy Rev. 2012, 16, 1477-1495. [CrossRef]

27. Toe, D.H.C.; Kubota, T. Comparative assessment of vernacular passive cooling techniques for improving indoor thermal comfort of modern terraced houses in hot-humid climate of Malaysia. Sol. Energy 2015, 114, 229-258. [CrossRef]

28. Singh, M.K.; Mahapatra, S.; Atreya, S.K. Thermal performance study and evaluation of comfort temperatures in vernacular buildings of North-East India. Build. Environ. 2010, 45, 320-329. [CrossRef]

29. Fernandes, J.; Pimenta, C.; Mateus, R.; Silva, S.M.; Bragança, L. Contribution of portuguese vernacular building strategies to indoor thermal comfort and occupants' perception. Buildings 2015, 5, 1242-1264. [CrossRef]

30. Fernandes, J.; Mateus, R.; Bragança, L.; Júlio, J.; Correia da Silva, J.J. Portuguese vernacular architecture: The contribution of vernacular materials and design approaches for sustainable construction. Archit. Sci. Rev. 2015, 58, 324-336. [CrossRef]

31. Fernandes, J.E.P.; Debaieh, M.; Mateus, R.; Silva, S.M.; Bragança, L.; Gervásio, H.; Paper, C.; Malm, M.D.; Approach, A.I.; Cycle, L.C. Engineering, Thermal performance and comfort of vernacular earthen buildings in Egypt and Portugal. In Sostierra 2017, 3rd ed.; CRC Press: Boca Raton, FL, USA, 2017; pp. 95-100.

32. Kubota, T.; Toe, D.H.C. Application of passive cooling techniques in vernacular houses to modern urban houses: A case study of Malaysia. Procedia Soc. Behav. Sci. 2015, 179, 29-39. [CrossRef]

33. Climates, V.D.; Alrashed, F.; Asif, M.; Burek, S. The Role of Vernacular Construction Techniques and Materials for Developing Zero-Energy Homes in Various Desert Climates. Buildings 2017, 7, 17. [CrossRef]

34. Du, X.; Bokel, R.; Van Den Dobbelsteen, A. Building microclimate and summer thermal comfort in free-running buildings with diverse spaces: A Chinese vernacular house case. Build. Environ. 2014, 82, 215-227. [CrossRef]

35. Kubota, T.; Zakaria, M.A.; Abe, S.; Toe, D.H.C.; Hooi, D.; Toe, C. Thermal functions of internal courtyards in traditional Chinese shophouses in the hot-humid climate of Malaysia. Build. Environ. 2017, 112, 115-131. [CrossRef]

36. Hazbei, M.; Nematollahi, O.; Behnia, M.; Adib, Z. Reduction of energy consumption using passive architecture in hot and humid climates. Tunn. Undergr. Space Technol. 2015, 47, 16-27. [CrossRef]

37. Chandel, S.S.; Sharma, V.; Marwah, B.M. Review of energy ef fi cient features in vernacular architecture for improving indoor thermal comfort conditions. Renew. Sustain. Energy Rev. 2016, 65, 459-477. [CrossRef]

38. Beccali, M.; Strazzeri, V.; Germanà, M.L.; Melluso, V.; Galatioto, A. Vernacular and bioclimatic architecture and indoor thermal comfort implications in hot-humid climates: An overview. Renew. Sustain. Energy Rev. 2017, 1-11. [CrossRef]

39. De Dear, R.J.; Brager, G.S. Thermal comfort in naturally ventilated buildings: Revisions to ASHRAE Standard 55. Energy Build. 2002, 34, 549-561. [CrossRef] 
40. De Dear, R.J. A global database of thermal comfort field experiments. ASHRAE Trans. 1998, $104,1141$.

41. International Organization for Standardization. ISO 7730, Ergonomics of the Thermal Environment-Analytical Determination and Interpretation of Thermal Comfort Using Calculation of the PMV and PPD Indices and Local Thermal Comfort; International Organization for Standardization: Geneva, Switzerland, 2005.

42. Nasrollahi, F. Office Buildings Energy Efficient: Energy Efficiency with the Architectural Design; Berlin University: Berlin, Germany, 2015.

43. Designbuilder. Available online: https:/ / www.designbuilder.co.uk/URL (accessed on 2 June 2018).

44. Iran Statistical Center. Census Results of General Population and Housing; Iran Statistical Center: Tehran, Iran, 2011.

(C) 2018 by the authors. Licensee MDPI, Basel, Switzerland. This article is an open access article distributed under the terms and conditions of the Creative Commons Attribution (CC BY) license (http://creativecommons.org/licenses/by/4.0/). 